\title{
Role of Lubiprostone on Gastrointestinal Motility
}

\author{
Jae Yeoul Jun
}

Department of Physiology, Chosun University School of Medicine, Gwangju, Korea

Article: Lubiprostone increases small intestinal smooth muscle contractions through a prostaglandin $\mathrm{E}$ receptor 1 $\left(E P_{1}\right)$-mediated pathway

Chan WW, Mashimo H

(J Neurogastroenterol Motil 2013;19:312-318)

Lubiprostone is a bicyclic fatty acid derivative of prostaglandin $\mathrm{E}_{1}$ used for the treatment of chronic idiopathic constipation and constipation predominant irritable bowel syndrome. ${ }^{1,2}$ The underlying mechanism of lubiprostone is stimulation of electrogenic chloride secretion by activating chloride channel type-2 $(\mathrm{ClC}-2)^{3}$ and cystic fibrosis transmembrane conductance regulator (CFTR) chloride channels ${ }^{4}$ in the apical membrane of the intestinal epithelial cells. Activation of ClC-2 channels or CFTR chloride channels in intestinal epithelial cells produces an active secretion of chloride ions from cells into the intestinal lumen followed by a passive secretion of electrolytes and water which increases the liquidity of the luminal contents. The luminal distension by increased intestinal fluid promotes the gastrointestinal (GI) tract motility which in turn increases the intestinal and colonic transit. Lubiprostone also has an effect on cystic fibrosis tissue by independent CFTR chloride channels. ${ }^{5}$ Lubiprostone induced chloride secretory action is mediated by direct activation of ClC-2 channels as well as stimulation of these channels through activating prostaglandin receptors. Besides, lubiprostone enhances and stimulates contraction in colonic as well as gastric muscles through prostaglandin $\mathrm{E}$ receptors $\left(\mathrm{EP}_{1}\right.$ or $\left.\mathrm{EP}_{4}\right){ }^{6}$, suggesting the modulatory effects of lubiprostone on GI motility through the ac- tivation of prostaglandin receptors.

In this issue of Journal of Neurogastroenterology and Motility, Chan and Mashimo ${ }^{7}$ investigated the effects of lubiprostone on intestinal smooth muscle contractions and pyloric sphincter tones from murine. They found that lubiprostone increased electrical field stimulation-induced contractions of intestinal circular smooth muscles and pyloric sphincter basal tone but not intestinal longitudinal smooth muscles. The excitatory effects of lubiprostone on intestinal circular smooth muscle and pyloric sphincter basal tone were blocked by $\mathrm{EP}_{1}$ antagonist. They speculated that lubiprostone can change the GI motility by prostaglandin receptor activation and the excitatory action of lubiprostone may be another mechanism for the increased intestinal transit and the delayed gastric emptying by lubiprostone. ${ }^{8}$ Although this study provides that lubiprostone has a role as a prokinetic agent in GI tract, the underlying mechanisms of modulating contractions were not evaluated. Many cells of GI tract express E-type prostanoid receptors including smooth muscle, neuron, macrophage and interstitial cells of Cajal that contribute to modulation of GI motility. ${ }^{9-11}$ Therefore, to evaluate the clinical effects of lubiprostone for modulating GI motility, further basic studies should be carried out to find underlying mechanisms.

Received: May 24, 2013 Revised: June 4, 2013 Accepted: June 6, 2013

(c) This is an Open Access article distributed under the terms of the Creative Commons Attribution Non-Commercial License (http://creativecommons. org/licenses/by-nc/3.0) which permits unrestricted non-commercial use, distribution, and reproduction in any medium, provided the original work is properly cited.

*Correspondence: Jae Yeoul Jun, MD, PhD

Department of Physiology, Chosun Univesity School of Medicine, 309, Pilmun-daero, Dong-gu, Gwangju 501-759, Korea

Financial support: None.

Tel: +82-62-230-6412, Fax: +82-62-232-4943, E-mail: jyjun@chosun.ac.kr

Conflicts of interest: None. 


\section{References}

1. Lembo AJ, Johanson JF, Parkman HP, Rao SS, Miner PB Jr, Ueno R. Long-term safety and effectiveness of lubiprostone, a chloride channel (ClC-2) activator, in patients with chronic idiopathic constipation. Dig Dis Sci 2011;56:2639-2645.

2. Drossman DA, Chey WD, Johanson JF, et al. Clinical trial: lubiprostone in patients with constipation-associated irritable bowel syndrome - results of two randomized, placebo-controlled studies. Aliment Pharmacol Ther 2009;29:329-341.

3. Lacy BE, Levy LC. Lubiprostone: a chloride channel activator. J Clin Gastroenterol 2007;41:345-351.

4. Bijvelds MJ, Bot AG, Escher JC, De Jonge HR. Activation of intestinal Cl- secretion by lubiprostone requires the cystic fibrosis transmembrane conductance regulator. Gastroenterology 2009;137:976985.

5. MacDonald KD, McKenzie KR, Henderson MJ, Hawkins CE, Vij N, Zeitlin PL. Lubiprostone activates non-CFTR dependent respiratory epithelial chloride secretion in cystic fibrosis mice. Am J Physiol Lung Cell Mol Physiol 2008;295:L933-L940.
6. Bassil AK, Borman RA, Jarvie EM, et al. Activation of prostaglandin EP receptors by lubiprostone in rat and human stomach and colon. Br J Pharmacol 2008;154:126-135.

7. Chan WW, Mashimo H. Lubiprostone increases small intestinal smooth muscle contractions through a prostaglandin $\mathrm{E}$ receptor 1 $\left(\mathrm{EP}_{1}\right)$-mediated pathway. J Neurogastroenterol Motil 2013;19:312318.

8. Camilleri M, Bharucha AE, Ueno R, et al. Effect of a selective chloride channel activator, lubiprostone, on gastrointestinal transit, gastric sensory, and motor functions in healthy volunteers. Am J Physiol Gastrointest Liver Physiol 2006;290:G942-G947.

9. Forrest AS, Hennig GW, Jokela-Willis S, Park CD, Sanders KM Prostaglandin regulation of gastric slow waves and peristalsis. Am J Physiol Gastrointest Liver Physiol 2009;296:G1180-G1190.

10. Tajima $\mathrm{T}$, Murata $\mathrm{T}$, Aritake $\mathrm{K}$, et al. $\mathrm{EP}_{2}$ and $\mathrm{EP}_{4}$ receptors on muscularis resident macrophages mediate LPS-induced intestinal dysmotility via iNOS upregulation through cAMP/ERK signals. Am J Physiol Gastrointest Liver Physiol 2012;302:G524-G534.

11. Choi S, Yeum $\mathrm{CH}$, Chang IY, et al. Activating of ATP-dependent $\mathrm{K}^{+}$channels comprised of $\mathrm{K}_{\mathrm{ir}} 6.2$ and SUR $2 \mathrm{~B}$ by $\mathrm{PGE}_{2}$ through $\mathrm{EP}_{2}$ receptor in cultured interstitial cells of Cajal from murine small intestine. Cell Physiol Biochem 2006;18:187-198. 